\title{
How to get published in Nature
}

\author{
Natalie DeWitt
}

Publication in top tier journals has become increasingly competitive, and the prestige of the journal is used to rank the strength and impact of scientific papers. In this overview of Nature Publishing Group, I will discuss what makes Nature titles distinct from other journals, the range of publishing options within NPG, and how the different journals within NPG interact. I will talk about the pre-submission inquiries, what happens to your paper once you submit it, the selection criteria that editors use for selecting which papers to have peer reviewed, and how editors select reviewers. I'll also provide advice from an editor's perspective on how you as an author can most effectively communicate with journal editors.

Cell Research (2008) 18:s178. doi: 10.1038/cr.2008.268; published online 4 August 2008

Correspondence: Natalie DeWitt

Natalie DeWitt is a Senior Editor of the San Francisco Bureau of Nature and Editor in Chief of Nature Reports Stem Cells. She has a BS in biochemistry from University of Maryland, a PhD in cell and molecular biology from the University of Wisconsin, and has carried out postdoctoral research at Princeton and Yale Universities. DeWitt joined Nature Publishing Group in 1999 as a research editor for Nat Biotechnol in the NPG New York office. In 2001, she moved to San Francisco, where she helped to found the first San Francisco editorial office for Nature. Since then, has handled scientific manuscripts in the area of stem cells, regenerative medicine and developmental biology. She also helped to launch Nature Reports Stem Cells, an online, interactive, community and news site for stem cell scientists and stakeholders launched in June 2007. 